\title{
Berberine Inhibits Telomerase Activity and Induces Cell Cycle Arrest and Telomere Erosion in Colorectal Cancer Cell Line, HCT 116
}

\author{
Muhammad Azizan Samad ${ }^{1}$, Mohd Zuwairi Saiman ${ }^{1,2}$, Nazia Abdul Majid ${ }^{1, *}$, , Saiful Anuar Karsani ${ }^{1}$ and \\ Jamilah Syafawati Yaacob 1,2,*(D) \\ 1 Institute of Biological Sciences, Faculty of Science, Universiti Malaya, Kuala Lumpur 50603, Malaysia; \\ azizan_12@siswa.um.edu.my (M.A.S.); zuwairi@um.edu.my (M.Z.S.); saiful72@um.edu.my (S.A.K.) \\ 2 Centre for Research in Biotechnology for Agriculture (CEBAR), Faculty of Science, Universiti Malaya, \\ Kuala Lumpur 50603, Malaysia \\ * Correspondence: nazia@um.edu.my (N.A.M.); jamilahsyafawati@um.edu.my (J.S.Y.); \\ Tel.: +60-3-7967-5833 (N.A.M.); +60-3-7967-4090 (J.S.Y.)
}

Citation: Samad, M.A.; Saiman, M.Z.; Abdul Majid, N.; Karsani, S.A.; Yaacob, J.S. Berberine Inhibits Telomerase Activity and Induces Cell Cycle Arrest and Telomere Erosion in Colorectal Cancer Cell Line, HCT 116 Molecules 2021, 26, 376. https:// doi.org/10.3390/molecules26020376

Received: 15 October 2020 Accepted: 18 December 2020 Published: 13 January 2021

Publisher's Note: MDPI stays neutral with regard to jurisdictional clai$\mathrm{ms}$ in published maps and institutional affiliations.

Copyright: (C) 2021 by the authors. Licensee MDPI, Basel, Switzerland. This article is an open access article distributed under the terms and conditions of the Creative Commons Attribution (CC BY) license (https:// creativecommons.org/licenses/by/ $4.0 /)$.

\begin{abstract}
Colorectal cancer (CRC) is the most common cancer among males and females, which is associated with the increment of telomerase level and activity. Some plant-derived compounds are telomerase inhibitors that have the potential to decrease telomerase activity and/or level in various cancer cell lines. Unfortunately, a deeper understanding of the effects of telomerase inhibitor compound(s) on CRC cells is still lacking. Therefore, in this study, the aspects of telomerase inhibitors on a CRC cell line (HCT 116) were investigated. Screening on HCT 116 at 48 h showed that berberine $(10.30 \pm 0.89 \mu \mathrm{g} / \mathrm{mL})$ is the most effective (lowest $\mathrm{IC}_{50}$ value) telomerase inhibitor compared to boldine $(37.87 \pm 3.12 \mu \mathrm{g} / \mathrm{mL})$ and silymarin $(>200 \mu \mathrm{g} / \mathrm{mL})$. Further analyses exhibited that berberine treatment caused $\mathrm{G}_{0} / \mathrm{G}_{1}$ phase arrest at $48 \mathrm{~h}$ due to high cyclin D1 (CCND1) and low cyclindependent kinase 4 (CDK4) protein and mRNA levels, simultaneous downregulation of human telomerase reverse transcriptase (TERT) mRNA and human telomerase RNA component (TERC) levels, as well as a decrease in the TERT protein level and telomerase activity. The effect of berberine treatment on the cell cycle was time dependent as it resulted in a delayed cell cycle and doubling time by 2.18-fold. Telomerase activity and level was significantly decreased, and telomere erosion followed suit. In summary, our findings suggested that berberine could decrease telomerase activity and level of HCT 116, which in turn inhibits the proliferative ability of the cells.
\end{abstract}

Keywords: colorectal cancer; HCT 116; telomerase; telomerase inhibitor; berberine; downregulation; cell cycle arrest; telomere erosion

\section{Introduction}

Colorectal cancer (CRC) $(10.2 \%$ incidence) is the third most common cancer among males and females worldwide after lung (11.6\% incidence) and breast cancers ( $11.6 \%$ incidence) [1]. CRC is often associated with an elevated telomerase level [2] and activity [3]. Telomerase is an enzyme responsible for adding the repetitive sequence (TTAGGG) at telomeric ends for telomere maintenance in humans [4]. Telomerase is a prognostic marker of CRC progression [3,5]. Patients with high telomerase activity have poorer prognosis and disease-free survival rates compared to those with low and moderate telomerase activity.

It has been previously suggested that human telomerase consists of six subunits, namely the human telomerase reverse transcriptase (hTERT or TERT), human telomerase RNA component ( $h T R$ or TERC), telomerase-associated protein 1 (TEP1), heat shock protein 90 (HSP90), prostaglandin E synthase 3 (P23), and dyskerin (DKC) [6]. However, recent review articles discussed that telomerase, which is synthesized during the $S$ phase, has more than just six subunits [7]. It has been shown that telomerase activity changed 
proportionally with the level of TERT but not with the other five subunits [6]. This could be due to the fact that TERT is the catalytic subunit of telomerase [8]. TERC is a functional RNA sequence that is responsible for providing a template for $3^{\prime}$ TTAGGG5' addition at telomere ends [4]. It was also stated that TERT and TERC are enough for telomerase to function [6]. Due to this reason, TERT and TERC serves as the prime target for telomerase level and activity inhibition. The most recent publication on the telomerase structure of the colorectal cancer cell line, HCT 116, surprisingly revealed that there were no TEP1, P23, and HSP90 subunits present [9]. This evidence agrees with the previous statement, whereby only TERT and TERC are required for telomerase to function. It might also suggest that telomerase could adopt different structures.

Since telomerase is the hallmark of CRC, targeting telomerase could be a potential treatment for telomerase-positive cancers, specifically CRC in this case. Many natural products have been listed as telomerase-targeting compounds or, in other words, telomerase inhibitors [10]. Boldine, silymarin, and berberine are some that are included in the list. Boldine is an alkaloid that could be found abundantly in the leaves of Peumus boldus, which has been used as a traditional medicine in Chile [11]. Silymarin is a collective name of seven flavonolignans, namely silydianin, isosilchristin, silychristin, silibinin (or silybin) A, isosilibinin (or isosilybin) A, silibinin B, and isosilibinin B, as well as one flavonoid named taxifolin [12,13], which is present in Silybum marianum (milk thistle) [14]. On the other hand, berberine is an alkaloid that can be found in the outer bark, roots, and rhizhome of Berberis spp, such as B. aristata, B. aquafolium, and B. vulgaris [15]. Besides that, berberine could also be extracted from Tinospora spp, such as T. sinensis and T. cordifolia [16]. These compounds have been reported to be able to downregulate telomerase activity and/or level in various cancer cell lines [10].

Telomerase is highly expressed in proliferative cells, such as cancer, stem, and gamete cells, but not in normal cells [17]. However, telomerase activity is higher in cancer cells compared to most stem cells except for embryonic stem cells [18]. It is challenging to determine whether telomerase inhibition will affect gamete and stem cells as cancer cells are affected; however, due to the shorter length of telomere as well as the difference of the metabolism in cancer cells, it would have undergone apoptosis even before it could adversely affect germ line and stem cells [17]. The aim of this study was to investigate the effects of telomerase inhibitor compound treatment on the cell cycle, doubling time $\left(t_{d}\right)$, telomerase activity, and level as well as on the telomere length of a colorectal cancer cell line, using HCT 116 as a model.

\section{Results}

2.1. Effect of Different Time Points on the Percentage of Cell Cycle Distribution and Relative Telomerase Activity (RTA)

It has been hypothesized that telomerase activity peaked during $S$ phase $[19,20]$, thus it was necessary to determine the time point that possessed the highest percentage of $S$ phase. Cell cycle analysis was done on HCT 116 cells at different time points to determine the percentage of cell cycle phases (Figure 1). Here, $72 \mathrm{~h}$ exhibited the highest percentage of $\mathrm{G}_{0} / \mathrm{G}_{1}$ phase $(35.13 \pm 0.25 \%)$ compared to $24 \mathrm{~h}$ and $48 \mathrm{~h}(27.17 \pm 5.14 \%$ and $24.63 \pm 0.67 \%$, respectively). Based on the results, the percentage of $S$ phase was significantly highest at $48 \mathrm{~h}(50.10 \pm 1.15 \%)$, followed by $24 \mathrm{~h}(43.43 \pm 1.59 \%)$ and $72 \mathrm{~h}(36.70 \pm 0.75 \%)$. The RTA of HCT 116 indeed peaked at $48 \mathrm{~h}(114.26 \pm 1.26 \%)$ followed by $24 \mathrm{~h}(98.69 \pm 0.42 \%)$ and $72 \mathrm{~h}(90.24 \pm 0.91 \%)$. All three time points gave an insignificant percentage of $\mathrm{G}_{2} / \mathrm{M}$ phase. Thus, $48 \mathrm{~h}$ was chosen for the treatment duration for subsequent experiments since it showed the highest percentage of $S$ phase and RTA. 
(A)

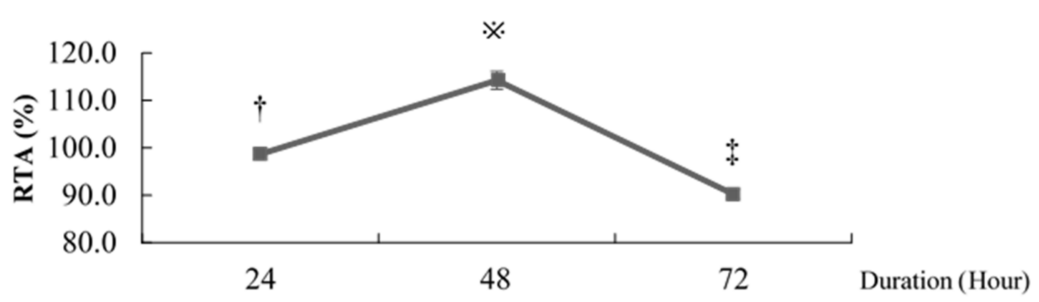

(B)

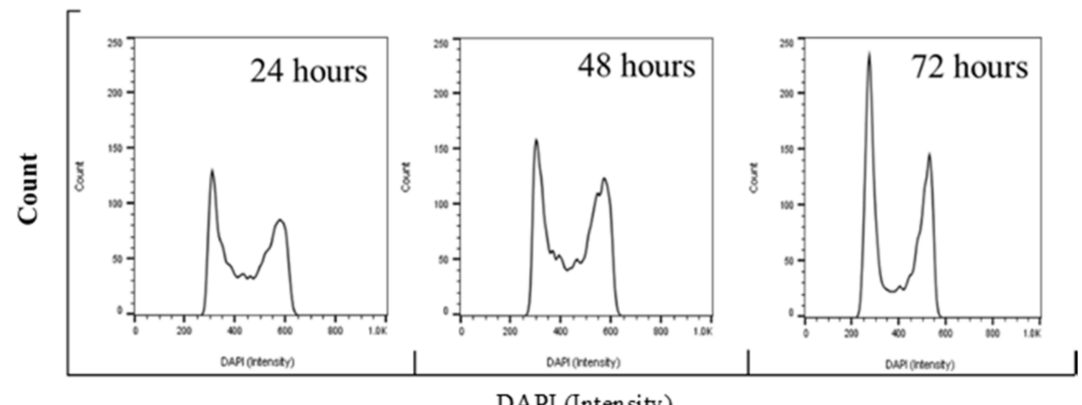

(C)

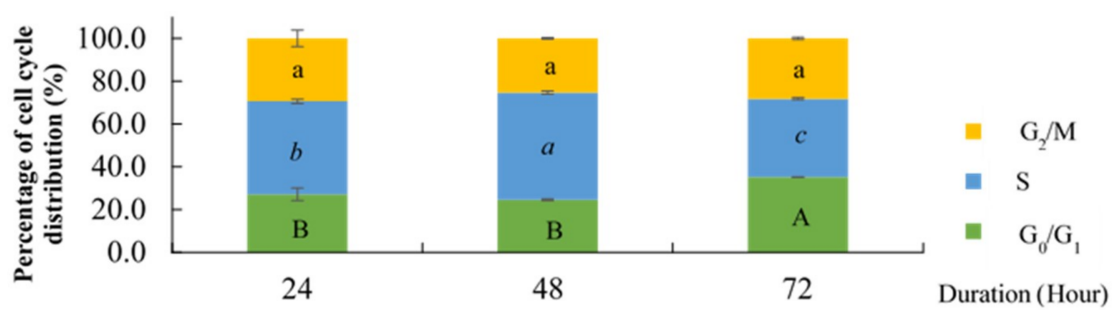

Figure 1. Effects of different time points on relative telomerase activity (RTA) and percentage of HCT 116 cell cycle distribution. (A) Telomerase activity of HCT 116 harvested at different time points relative to telomerase-positive control (HEK293). Values are mean \pm standard error of triplicate. Mean with different symbols $(\uparrow, ※$, or $\ddagger$ ) differ significantly at $p<0.001$. (B) Representative cell cycle histogram of HCT 116 harvested at different time points stained with DAPI and analyzed by flow cytometry. (C) Percentage of cell cycle distribution of HCT 116 at different time points analyzed by FlowJo version 10. Values are mean \pm standard error of triplicate. Mean with different letters differ significantly at $p<0.05$ (subject to different cell cycle phases). G: Growth, S: Synthesis, M: Mitosis.

\subsection{Effect of Different Telomerase Inhibitor Compounds on $I C_{50}$}

HCT 116 cultured in 96-well plates treated with different concentrations of boldine, silymarin, or berberine for $48 \mathrm{~h}$ were subjected to SRB assay to determine the percentage of inhibition and the results were interpreted as $\mathrm{IC}_{50}$ (compound concentration required to inhibit HCT 116 by $50 \%$ ). Berberine was found to be the most effective, as it showed the lowest $\mathrm{IC}_{50}$ compared to boldine and silymarin (Table 1 ). Hence, berberine was chosen to be used for subsequent analysis.

Table 1. Effect of different telomerase inhibitor compound treatments on $\mathrm{IC}_{50}$. Values are mean \pm standard error of 6 replicates. Mean with different letters differ significantly at $p<0.05$.

\begin{tabular}{cccc}
\hline Compound & Boldine & Silymarin & Berberine \\
\hline $\mathrm{IC}_{50}(\mu \mathrm{g} / \mathrm{mL})$ & $37.87 \pm 3.12^{\mathrm{b}}$ & $>200^{\mathrm{c}}$ & $10.30 \pm 0.89^{\mathrm{a}}$ \\
\hline
\end{tabular}

\subsection{Effect of Berberine Treatment on Cell Cycle Distribution}

The cells were treated with berberine for $48 \mathrm{~h}$ and were analyzed for cell cycle distribution. Treatment with berberine was observed to cause a cell cycle arrest at $G_{0} / G_{1}$ phase, as shown by the significant increase in the number of cells in $G_{0} / G_{1}$ compared to that of 
untreated sample (Figure 2). The cells in $\mathrm{S}$ phase remained unchanged while the cells also did not proceed to $G_{2} / M$, as indicated by a significant decrement of $G_{2} / M$.

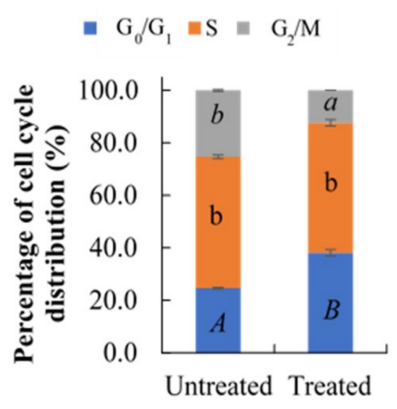

Figure 2. Effect of $10.54 \mu \mathrm{g} / \mathrm{mL}$ berberine treated HCT 116 at $48 \mathrm{~h}$ on the percentage of cell cycle distribution. Values are mean \pm standard error of triplicate. Mean with different letters differ significantly at $p<0.001$ (subject to different cell cycle phases).

The cells were also exposed to berberine at various time points, to determine if the effects observed were time dependent. Based on Figure 3, the $G_{0} / G_{1}$ percentage started to increase gradually after $12 \mathrm{~h}$ and became constant after $48 \mathrm{~h}$. The percentage of cells in $\mathrm{S}$ phase significantly decreased from 0 to $6 \mathrm{~h}$ after treatment, then started to increase again from 12 to $24 \mathrm{~h}$, then became stable at $48 \mathrm{~h}$ followed by a slight decrement at $72 \mathrm{~h}$; however, the percentages of $S$ phase at 24 and $72 \mathrm{~h}$ were not significantly different. $\mathrm{G}_{2} / \mathrm{M}$ started to increase from 0 to $6 \mathrm{~h}$ after treatment, then decreased from 12 to $24 \mathrm{~h}$, stabilized at $48 \mathrm{~h}$, and then slightly increased at $72 \mathrm{~h}$. This scenario showed that the effect of berberine on cell cycle was time dependent.

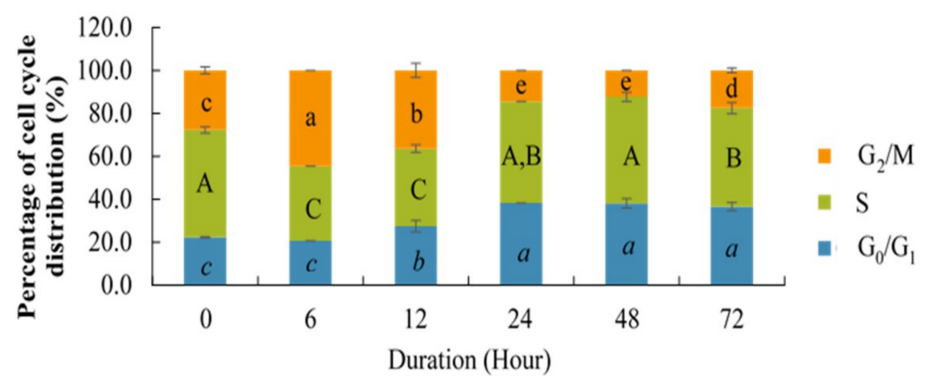

Figure 3. Changes in the percentage of HCT 116 cells in $G_{0} / G_{1}, S$, and $G_{2} / M$ phases at different durations following treatment with $10.54 \mu \mathrm{g} / \mathrm{mL}$ berberine. Values are mean \pm standard error of triplicate. Mean with different letters differ significantly at $p<0.001$ (subject to different cell cycle phases).

\subsection{Effect of Berberine Treatment on Cell Growth and Berberine Cellular Localization}

The time-dependent effect of berberine on HCT 116 could also be observed microscopically. Based on Table 2, it was observed that the cell growth was inhibited by berberine treatment. The difference in growth could be clearly observed at 48 and $72 \mathrm{~h}$. Figure $4 \mathrm{~A}$ also showed that berberine treatment caused the doubling time $\left(t_{d}\right)$ of HCT 116 to be delayed. The green fluorescence intensity observed under the UV channel peaked at $24 \mathrm{~h}$, then decreased at $72 \mathrm{~h}$ (see Figure $4 \mathrm{~B}$ ). It was also noted that at $24 \mathrm{~h}$, the nuclei appeared as black round hollows surrounded by green fluorescence, which potentially indicates that berberine had permeated and accumulated in the cytoplasm. The black hollows were no longer observed after 48 and $72 \mathrm{~h}$, suggesting that berberine had permeated and accumulated in the nuclei. Untreated HCT 116 did not fluoresce at all under the UV channel and the image only appeared as black. 
Table 2. Effect of $10.54 \mu \mathrm{g} / \mathrm{mL}$ berberine treatment on HCT 116 growth at different durations. Berberine emitted green fluorescence under the ultraviolet (UV) channel of an inverted microscope. White arrows indicate nuclei appeared as black, round hollows surrounded by green fluorescence. Black scale bar $=100 \mu \mathrm{m}$. Yellow scale bar $=20 \mu \mathrm{m}$.

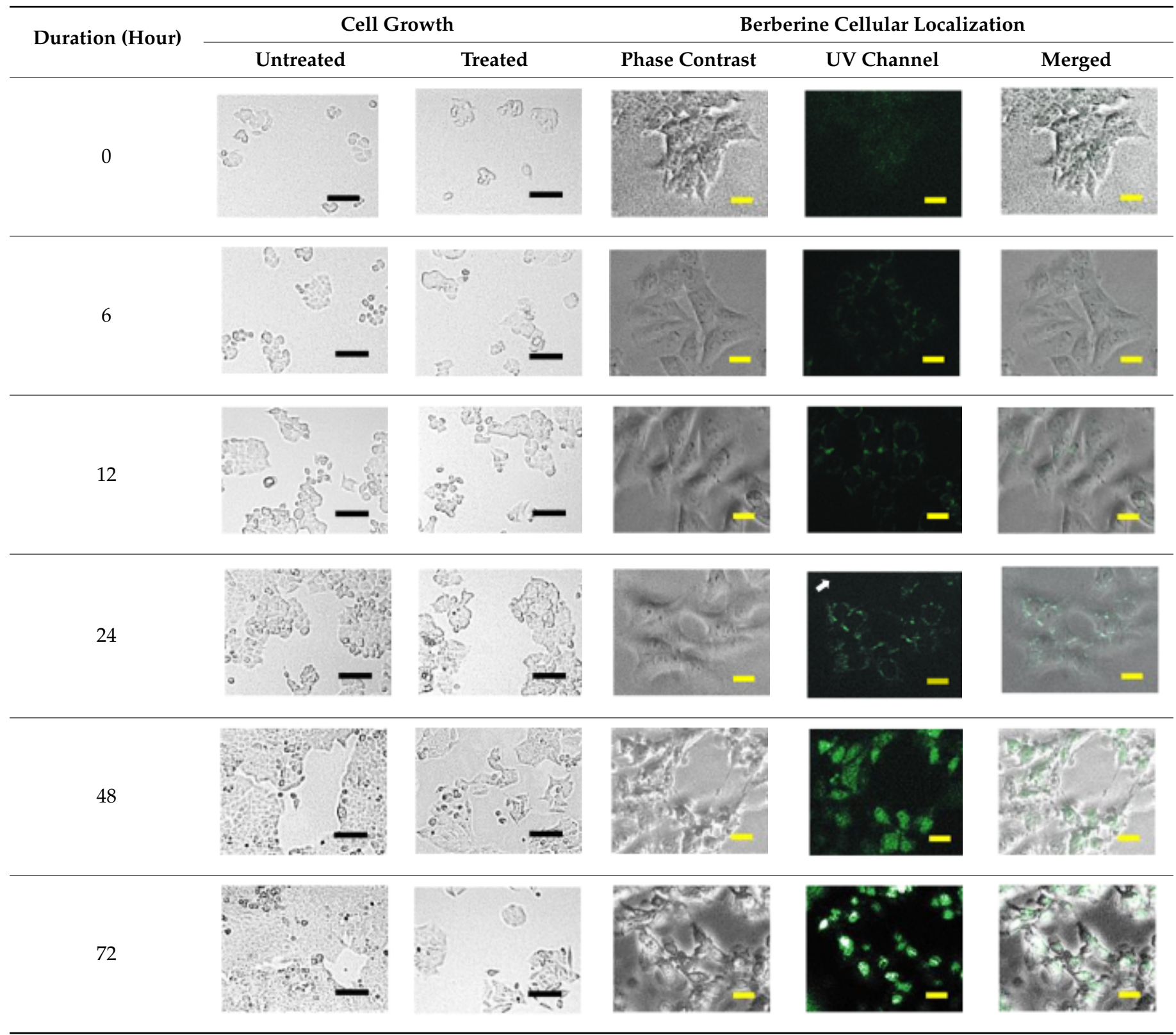



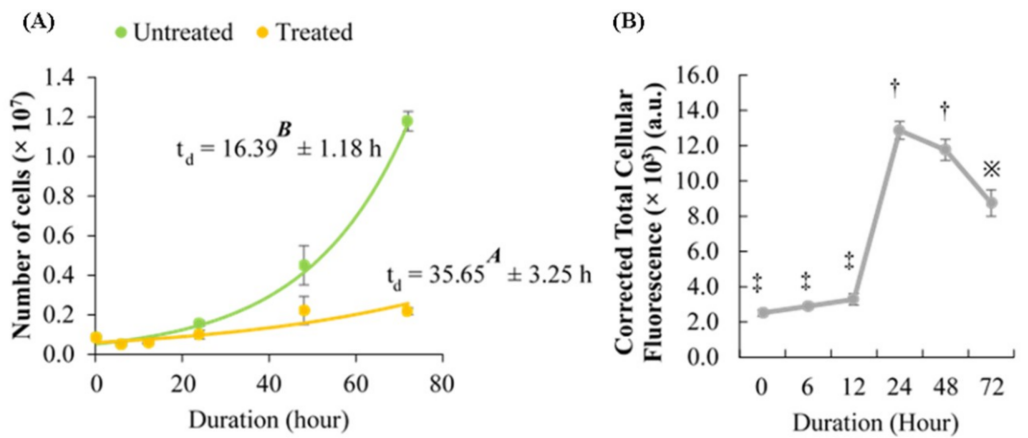

Figure 4. (A) Growth curve of untreated and $10.54 \mu \mathrm{g} / \mathrm{mL}$ berberine-treated HCT 116. Values are mean \pm standard error of biological quadruplicate. $t_{d}$ : doubling time. (B) Corrected Total Cellular Fluorescence (CTCF) of berberine-treated HCT 116 at different durations. Values are mean \pm standard error of biological triplicate. a.u.—arbitrary unit. Mean with different letters or symbols $(\ddagger, \uparrow$, or $※)$ differ significantly at $p<0.001$.

\subsection{Effect of Berberine Treatment on Relative Telomerase Activity (RTA)}

Berberine-treated HCT 116 at $48 \mathrm{~h}$ were analyzed by using TELOTAGGG Telomerase PCR ELISA. The telomerase activity was observed to significantly decrease with berberine treatment (Figure 5). Compared to untreated HCT 116, the RTA in berberine-treated HCT 116 was decreased by $63.22 \%$. To evaluate cell-free telomerase inhibition, berberine was added into the TRAP reaction mixture to the same final concentration and the results showed that berberine only decreased the RTA by $16.10 \%$ (see Figure A1). This might suggest that the inhibition of telomerase-TTAGGG interaction was not the only reason for the decrement in the RTA, whereby the level of telomerase might be affected, which caused the RTA to decrease even further. As such, we are interested in investigating the effect of berberine on TERT and TERC levels.

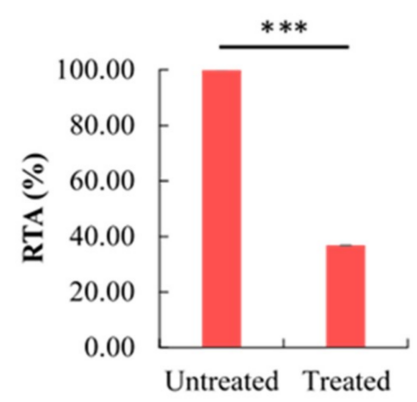

Figure 5. Effect of $10.54 \mu \mathrm{g} / \mathrm{mL}$ berberine-treated HCT 116 at $48 \mathrm{~h}$ on relative telomerase activity (RTA). Values are mean \pm standard error of triplicate. Means with ${ }^{* * *}$ (triple asterisks) differ significantly at $p<0.001$.

\subsection{Effect of Berberine Treatment on CCDN1, CDK4, TERT, and TERC RNA Levels}

In cell cycle progression, CCND1 and CDK4 are important regulators for $\mathrm{G}_{1}$ to $\mathrm{S}$ phase transition, whereby the binding of CCND1 to CDK4 is a rate-limiting event [21]. Since $G_{0} / G_{1}$ phase arrest was observed (Figure 2), we are keen to know the effect of berberine on the RNA levels of these regulators. Based on the RT-PCR results (Figure 6), surprisingly, $10.54 \mu \mathrm{g} / \mathrm{mL}$ berberine treatment caused CCND1 level to be upregulated by 1.71-fold. Besides that, CDK4, TERT, and TERC levels were downregulated by 1.26-, 108.15-, and 2.80 -fold, respectively. 

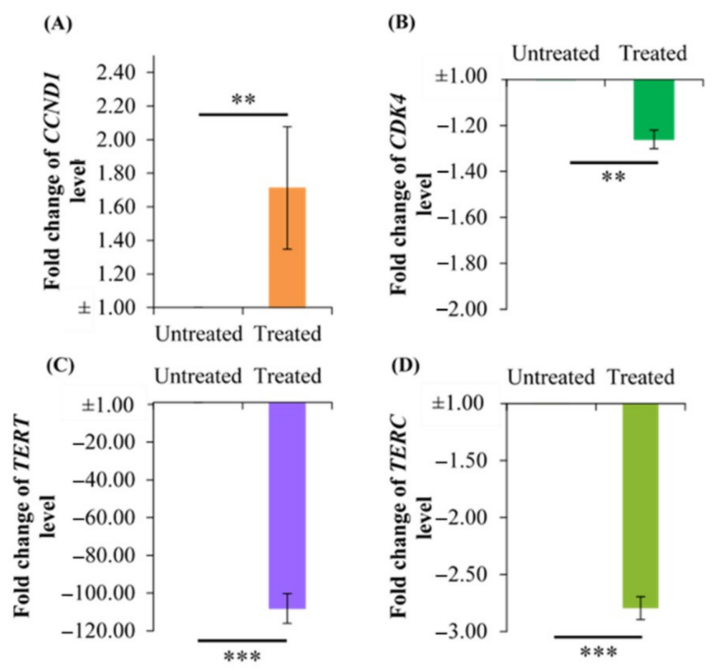

Figure 6. Effect of $10.54 \mu \mathrm{g} / \mathrm{mL}$ berberine-treated HCT 116 at $48 \mathrm{~h}$ on (A) CCND1, (B) CDK4, (C) TERT, and (D) TERC levels. Changes in RNA levels are expressed as fold change in RNA levels relative to untreated HCT 116 at $48 \mathrm{~h}$. Values are mean \pm standard error of quadruplicate. Mean with ** (double asterisks) or *** (triple asterisks) differ significantly at $p<0.01$ or $p<0.001$, respectively.

\subsection{Effect of Berberine Treatment on CCND1, CDK4, and TERT Protein Levels}

Parallel to the downregulation of CDK4 and TERT mRNA levels, validation by Western blot results (Figure 7) also showed that berberine treatment at $48 \mathrm{~h}$ caused CDK4 and TERT protein levels to decrease significantly by $45.16 \%$ and $73.29 \%$, respectively. Besides this, the CCND1 protein level increased significantly by $95.77 \%$.

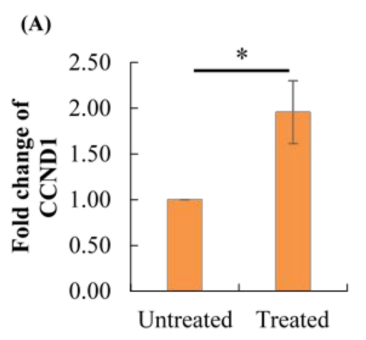

(C)

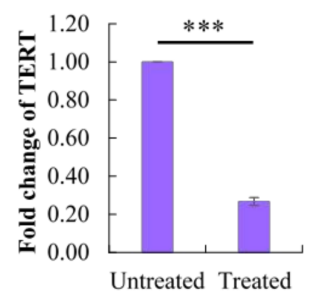

(B)

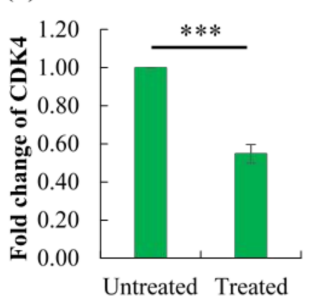

(D)

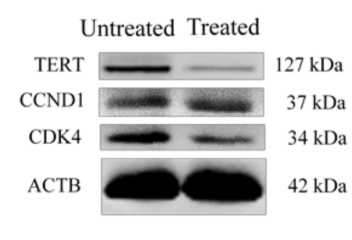

Figure 7. Effect of $10.54 \mu \mathrm{g} / \mathrm{mL}$ berberine-treated HCT 116 at $48 \mathrm{~h}$ on (A) CCND1, (B) CDK4, and (C) TERT protein levels. Changes in CCND1, CDK4, and TERT protein levels are expressed as fold change in CCND1, CDK4, and TERT signal intensities, respectively, normalized to ACTB relative to untreated HCT 116 at 48 h. (D) Representative Western blot images of TERT, CCND1, CDK4, and ACTB. Values are mean \pm standard error of triplicate. Mean with * (single asterisk) or ** (triple asterisks) differ significantly at $p<0.05$ or $p<0.001$, respectively.

\subsection{Effect of Berberine Treatment on Relative Telomere Length}

Consistent with the significantly impaired telomerase activity and level by berberine treatment, telomere attrition also occurred as anticipated (Figure 8), whereby the relative 
telomere length of berberine-treated HCT 116 after $48 \mathrm{~h}$ was $0.81 \pm 0.08$, compared to untreated HCT 116 (with a relative telomere length of 1.0).

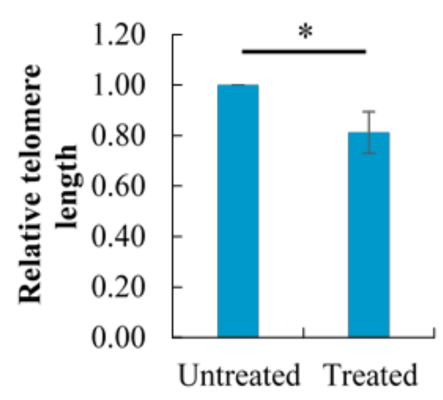

Figure 8. Effect of $10.54 \mu \mathrm{g} / \mathrm{mL}$ berberine-treated HCT 116 at $48 \mathrm{~h}$ on the relative telomere length. Changes in telomere length are expressed as fold change relative to untreated HCT 116 at $48 \mathrm{~h}$. Values are mean \pm standard error of octuplicate. Mean with * (single asterisk) differ significantly at $p<0.05$.

\section{Discussion}

The cytotoxicity of drugs could be classified into cytotoxic (less than $2 \mu \mathrm{g} / \mathrm{mL}$ ), moderately cytotoxic (between 2 to $89 \mu \mathrm{g} / \mathrm{mL}$ ), and not cytotoxic (more or equal to $90 \mu \mathrm{g} / \mathrm{mL}$ ) based on their $\mathrm{IC}_{50}$ values [22]. In the present study, berberine and boldine were found to be moderately cytotoxic, while silymarin was not cytotoxic to HCT 116 after $48 \mathrm{~h}$ of treatment. Since silymarin did not reach $\mathrm{IC}_{50}$, the value was reported as $>200 \mu \mathrm{g} / \mathrm{mL}$, which was greater than the highest tested concentration as suggested by the National Cancer Institute [23].

In several telomerase-positive cancer cell lines, berberine treatment has been shown to cause $\mathrm{G}_{0} / \mathrm{G}_{1}$ phase arrest in MCF-7 (breast cancer) after $48 \mathrm{~h}$ [24], Huh-7 and HEPG2 (liver cancers) in a dose-dependent manner after $24 \mathrm{~h}$ [25], and A2780 (ovarian cancer) after $48 \mathrm{~h}$ of treatment [26]. Either too high or too low CCND1 levels would compromise cell cycle progression [27]. In the present study, it was revealed that an abnormal level of cell cycle regulators, in this case high CCND1 levels and low CDK4 levels, would lead to $G_{0} / G_{1}$ phase arrest in HCT 116. Since the binding of CCND1 to CDK4 is a rate-limiting event in $G_{1}$ to $S$ phase transition [21], theoretically, the effect of berberine on $G_{0} / G_{1}$ arrest would depend mainly on these two proteins instead of other cyclins and CDKs. Besides that, telomerase is mostly active during $S$ phase, hence the reason the study was focused more on CCND1 and CDK4 instead of other cyclins and CDKs. Due to this reason, the experiments were designed in such flow, so that the study was more focused to the factors that are associated within the telomerase aspect.

Wang, et al. [28] reported that $G_{0} / G_{1}$ arrest in U87 and LN229 (brain cancer) was caused by the downregulation of miR-21, which caused a decrement of STAT3 phosphorylation and protein level, thus causing the TERT protein level to decrease. In a separate study, berberine showed the ability to repress the miR-21 level in oral squamous cell carcinoma cancer stem cell lines (OECM-1 and SAS), which decreased aldehyde dehydrogenase 1 (ALDH1) activity, cell migration, invasion capability, and self-renewal [29]. Moreover, $\mathrm{G}_{0} / \mathrm{G}_{1}$ phase arrest in HL-60 (leukemia) is also associated with a decrement of telomerase activity as well as TERT and TERC levels [30]. It was also previously shown that berberine treatment for $24 \mathrm{~h}$ induced $\mathrm{G}_{0} / \mathrm{G}_{1}$ phase arrest in HCT 116 in a dose-dependent manner [31]. Based on these previous findings, it would be fair to remark that the inhibition of cell proliferation (Figure 4 ) and $\mathrm{G}_{0} / \mathrm{G}_{1}$ phase arrest in $\mathrm{HCT} 116$ induced by berberine treatment were not exclusively caused by the downregulation of TERT.

Based on various references, the average duration of untreated HCT 116 cell cycle was about $17 \mathrm{~h}(16.88 \pm 2.56 \mathrm{~h})$ [32-36]. Therefore, theoretically, the second round of HCT 116 cell cycle would take place approximately after $34 \mathrm{~h}$. Based on Figure $4 \mathrm{~A}$, the average doubling time $\left(t_{d}\right)$ for untreated HCT 116 was $16.39 \pm 2.36 \mathrm{~h}$, similar to the average $t_{d}$ 
of previous findings. The average $t_{d}$ of berberine-treated HCT 116 was $35.65 \pm 6.50 \mathrm{~h}$, significantly higher than the average $t_{d}$ of untreated HCT 116. Data analysis revealed that the $t_{d}$ of berberine-treated HCT 116 was overdue by approximately two-fold (2.18-fold).

The localization of berberine in nuclei after $48 \mathrm{~h}$ further strengthens our justification of choosing this time point for further investigation. This is due to the fact that the transcription, synthesis, and activity of telomerase mainly takes place in the nucleus [7,37]. Since we are targeting the telomerase, berberine should be present in the nucleus for telomerase inhibition to occur. Here, we have demonstrated that berberine cellular localization is time dependent. Similarly, berberine cellular localization has also been shown to be concentration [38] and cell line dependent [39].

It was previously established that berberine treatment on HCT 116 inhibits cell proliferation in a dose- and time-dependent manner [31,40], and induced apoptosis in a dose-dependent manner at 24 [40] and 72 h [31]. Downregulation of TERT levels has been associated with a decrement in telomerase activity $[19,30,41]$ and vice versa [42]. Berberine intervenes in the function of telomerase through binding to the telomeric G-quadruplex structure [43,44], thus preventing the interaction between telomerase and telomere [45]. It was revealed in previous studies that berberine had the potential to regulate gene transcription $[46,47]$. Other than that, the decrement of the TERT protein level was often associated with downregulation of TERT mRNA [28] and vice versa [42]. Berberine could downregulate the TERT protein level in the non-small-cell lung cancer cell line, A549 [48], and cervical cancer cell lines, SiHa and HeLa [15]. Previous studies mostly focused only on the potential of berberine in downregulation of the TERT level; however, in the present study, we demonstrated that berberine could also downregulate the TERC level.

Berberine has been shown to decrease the telomerase level and activity, which is significantly followed by telomere erosion. Interestingly, by conducting telomere restriction fragment (TRF) analysis, Xiong et al. [49] revealed that prolonged exposure to berberine for 16 days did not significantly cause telomere shortening in SiHa and HL-60. This could possibly be due to the limitation of TRF, which could potentially overestimate the telomeric length compared to RT-PCR, which is more sensitive and specific [50]. Other than the potential to regulate gene transcription, berberine could interact directly with the telomeric G-quadruplex, whereby the interaction occurred between the negatively charged oxygen of guanine and positively charged nitrogen of berberine [51] with a molar ratio of 2:1 (berberine to G-tetrad) [52], as it stabilized the structure by increasing the melting temperature and as a result, telomerase activity was inhibited [53]. Berberine has been extensively studied in various cancer cell lines; however, in animal models, evidence to support the effects of berberine as a telomerase inhibitor on colorectal cancer is still lacking [54]. Berberine is effective at inhibiting polyps formation [55] and colon tumorigenesis in mice [40], however, currently, there is no in vivo study that validates berberine's presence in the nucleus of in vivo cancer cells of mice after oral administration of berberine. Since berberine is currently used in clinical trials (NCT03281096 and NCT03333265), there is an urge to elucidate berberine mechanisms as an anti-colorectal cancer drug.

In this study, cells from four flasks (biological replicates) were pooled to obtain sufficient material for several different analyses. All extractions and preparations were also performed from the same set of samples for the sake of uniformity. Although pooling of samples may rightfully raise some concerns, it is still widely viewed as a valid method, saves cost, and reduces biological variance, while not seriously affecting the results when compared to un-pooled samples [56-58]. Biological replicates and independent experiments are important to validate the effect of any anticancer drug due to the existence of heterogeneity the within cancer cell population. It was fully acknowledged that the lack of an independent experiment is a limitation in the current study. Though the potential mechanism of telomerase inhibition by berberine using HCT 116 as a model has been shown in the current study, further deeper understanding is vital to elucidate the potential of berberine as a telomerase inhibitor in CRC. 


\section{Materials and Methods}

\subsection{Reagents, Primers, and Antibodies}

Berberine was diluted in autoclaved Milli- ${ }^{\circledR}$ water and sterilized by filtration through a Minisart ${ }^{\circledR} 0.22 \mu \mathrm{m}$ polyethersulfone filter syringe (Sartorius Stedim Biotech, Göttingen, Germany). Boldine and silymarin was dissolved in dimethylsulfoxide (DMSO) and filtered as well. All primers were synthesized by Integrated DNA Technologies (IDT, Coralville, IA, USA). Monoclonal antibodies of CCND1 (A-12), CDK4 (DCS-31), TERT (A-6), and $\beta$-actin (ACTB) (AC-15) as well as mouse IgG kappa binding protein conjugated to horseradish peroxidase (m-IgGk BP-HRP) were obtained from Santa Cruz Biotechnology (Santa Cruz, Dallas, TX, USA). Molecular-grade absolute ethanol (Merck, Darmstadt, Germany) was diluted with autoclaved Milli- $Q^{\circledR}$ water. All reagents were from Sigma-Aldrich unless mentioned otherwise.

\subsection{Cell Culture and Harvesting}

Colorectal cancer cell line, HCT 116, was cultured in Roswell Memorial Institute (RPMI) medium 1640 (Nacalai Tesque, Kyoto, Japan) supplemented with 10\% fetal bovine serum (Tico Europe Ltd., Amstelveen, The Netherlands), 1\% Antibiotic-Antimycotic solution (Nacalai Tesque, Kyoto, Japan), maintained at $37{ }^{\circ} \mathrm{C}$ in a humidified $5 \% \mathrm{CO}_{2}$-enriched atmosphere (ESCO, Horsham, PA, USA). Cells were rinsed by using $1 \times$ phosphate-buffered saline (PBS) (Nacalai Tesque, Kyoto, Japan), repeated three times, and cells were detached by using trypsin-EDTA (Life Technologies, Burlington, Canada), followed by RPMI addition to stop the trypsinization; cells were pelleted by centrifugation at $1000 \mathrm{rpm}$, resuspended in RPMI for sub-culturing or seeding purpose, or $1 \times$ PBS was used to resuspend for harvesting as a washing step, followed by second-time pelleting of the cells. During harvesting, after observation under the microscope and cell count was conducted, cells from four flasks were pooled and pelleted in the amount as required for further analyses. The microcentrifuge tubes containing a pelleted known number of cells were immediately flash frozen in liquid nitrogen before storage in $-80^{\circ} \mathrm{C}$ until further usage.

\subsection{Cell Cycle Analysis}

In total, $1 \times 10^{6}$ pelleted cells in $2 \mathrm{~mL}$ microcentrifuge tube were washed with $1 \mathrm{~mL}$ of sample buffer ( $1 \times$ PBS containing $1 \mathrm{~g} / \mathrm{L}$ glucose) once by vortexing briefly, followed by centrifugation at $17,000 \times g$ for $5 \mathrm{~min}$. The supernatant was removed and about $0.1 \mathrm{~mL}$ was left in the tube. Then, $1 \mathrm{~mL}$ of $70 \%$ ethanol $\left(-20^{\circ} \mathrm{C}\right)$ was slowly added, $100 \mu \mathrm{L}$ at a time, drop by drop while vortexing. The suspension was stored at $4{ }^{\circ} \mathrm{C}$ for $24 \mathrm{~h}$. After fixation, $1 \mathrm{~mL}$ of sample buffer was added while vortexing, followed by centrifugation at $17,000 \times g$ for $10 \mathrm{~min}$. Staining solution made up of $0.5 \mu \mathrm{g} / \mathrm{mL} 4^{\prime}, 6$-diamidino-2-phenylindole (DAPI) (Miltenyi Biotec, Bergisch Gladbach, Germany), $5 \mu \mathrm{g} / \mathrm{mL}$ RNase A, and 0.1\% Tween 20 (Classic Chemicals, Shah Alam, Selangor, Malaysia) in $1 \times$ PBS was prepared immediately before incubation. The supernatant was removed, and $1 \mathrm{~mL}$ of staining solution was added followed by vortexing and incubation at room temperature for $40 \mathrm{~min}$. Flow cytometry was done by using a MACSQuant ${ }^{\circledR}$ Analyzer (Miltenyi Biotec, Bergisch Gladbach, Germany) following the protocol suggested by Miltenyi Biotec with optimizations. The fluorescence channel was set to $\mathrm{V} 1$ and measured by linear acquisition. The V1 voltage was set to $334 \mathrm{~V}$ and the trigger was set to 128.00 . The number of events was set to 10,000 events for each replicate. The data was analyzed by using FlowJo version 10 .

\subsection{Sulforhodamine B (SRB) Assay}

In total, 5000 cells $/ 100 \mu \mathrm{L}$ per well were seeded in 96-well plates, incubated at $37^{\circ} \mathrm{C}$ in a humidified $5 \% \mathrm{CO}_{2}$-enriched incubator for $24 \mathrm{~h}$ before compound treatments. The spent medium was pipetted out and replaced with $150 \mu \mathrm{L}$ of RPMI containing either boldine, silymarin, or berberine at various concentrations $(0.20,0.39,0.78,1.56,3.13,6.25,12.50$, $25.00,50.00,100.00$, and $200.00 \mu \mathrm{g} / \mathrm{mL}$ ) achieved by serial dilutions as well as RPMI without any of the named compounds as untreated (control). The treatments were done for $48 \mathrm{~h}$. 
After 48 h, each plate was subjected to Sulforhodamine B (SRB) assay [59]. Total protein content of viable cells was assessed in this assay. The plate was shaken on an ELISA microplate reader (Tecan, Männedorf, Switzerland) for $5 \mathrm{~min}$ and the absorbance was read at $492 \mathrm{~nm}$. The percentage of inhibition was calculated as the following:

$$
\text { Percentage of inhibition }(\%)=\frac{\mathrm{Abs}_{\text {untreated }}-\mathrm{Abs}_{\text {treated }}}{\mathrm{Abs}_{\text {untreated }}} \times 100 \%
$$

where $\mathrm{Abs}_{\text {untreated }}=$ Absorbance of untreated cells at $492 \mathrm{~nm}$; and $\mathrm{Abs}_{\text {treated }}=\mathrm{Absorbance}$ of berberine treated cells at $492 \mathrm{~nm}$.

Graphs of the percentage of inhibition against the concentration were plotted by using GraphPad Prism 7.00 by performing the 4-parameter logistic model (4PL) [60] and the $\mathrm{IC}_{50}$ values was determined by using the software. The cells were also cultured in T75 flasks to scale-up the production of HCT116 cells for subsequent analysis and were also used to determine a new $\mathrm{IC}_{50}$ value (for berberine).

\subsection{Cell Count and Growth Curve Analysis}

Cell count was done by using Trypan blue (TB) exclusion assay. In total, $100 \mu \mathrm{L}$ of the cell suspension were pipetted into a microcentrifuge tube and $100 \mu \mathrm{L}$ of Trypan blue (Nacalai Tesque, Kyoto, Japan) were gently mixed by pipetting in and out. The Trypan blue-dyed cells were then pipetted to fill up both chambers of a hemocytometer (Electron Microscopy Sciences, Hatfield, PA, USA), followed by observation and cell counting under an inverted microscope. Dead cells were stained blue while living cells were not stained. The average number of cells at each time point was used to plot the exponential growth curve following this equation:

$$
y=y_{0} e^{\lambda t}
$$

where $y=$ Final number of cells; $y_{0}=$ Initial number of cells; $e=$ Euler's number; $\lambda=$ Growth rate; $\mathrm{t}=$ Time that has passed; and the $\mathrm{t}_{\mathrm{d}}$ was calculated using the following equation:

$$
\mathrm{t}_{\mathrm{d}}=\ln 2 / \lambda
$$

\subsection{Berberine Cellular Localization}

Cells were observed by using a Leica DMI6000 B inverted microscope (Leica Microsystems, Wetzlar, Germany) under the phase contrast channel. Without changing the position, the channel was changed to UV to observe berberine fluorescence. To avoid cellular damage by UV radiation, the exposure was kept as minimal as possible, whereby the channel was shut off within $30 \mathrm{~s}$ (or less) after capturing the image by using a Digital Color Camera Leica DFC310 FX (Leica Microsystems, Wetzlar, Germany). The corrected total cellular fluorescence (CTCF) was determined by using a free software, ImageJ version 1.52a [61], by using the following equation:

$$
\mathrm{CTCF}=\operatorname{IntDen}_{\mathrm{cell}}-\left(\mathrm{A}_{\text {cell }} \times \overline{\mathrm{X}}_{\text {background }}\right)
$$

where IntDen $_{\text {cell }}=$ Integrated density of selected cell; $\mathrm{A}_{\text {cell }}=$ Area of selected cell; and $\bar{X}_{\text {background }}=$ Average background fluorescence reading.

\subsection{TELOTAGGG Telomerase PCR ELISA}

Protein extraction was done based on the protocol of the TELOTAGGG Telomerase PCR ELISA kit (Roche, Mannheim, Germany) with minor adjustments, whereby $5 \times 10^{5}$ cells were used. The protein content was assessed by Bradford Assay (Bio-Rad Laboratories, Hercules, CA, USA) as suggested by the Bio-Rad protocol. The Telomeric Repeat Amplification Protocol (TRAP) reaction was done using a thermal cycler, StepOnePlus ${ }^{\mathrm{TM}}$ Real Time-Polymerase Chain Reaction (RT-PCR) Systems (Applied Biosystems, Foster City, CA, USA). In total, $2 \mu \mathrm{g}$ of lysate were used in this reaction. 


\subsection{RT-PCR}

RNA extraction was conducted using the protocol of the ReliaPrep ${ }^{\mathrm{TM}}$ RNA Cell Miniprep System (Promega, Madison, WI, USA) with minor adjustments, whereby $1 \times 10^{6}$ cells harvested were lysed and DNase I treatment was done for $1 \mathrm{~h} 30 \mathrm{~min}$ at $30{ }^{\circ} \mathrm{C}$. RNA extracted was quantified by using a NanoDrop ${ }^{\mathrm{TM}} 2000$ (Thermo Fischer Scientific, Waltham, MA, USA). The purity was also assessed using the same instrument based on the A260/280 and A260/230 ratios. RNA integrity was evaluated using $1 \%$ native agarose gel electrophoresis containing $5 \mu \mathrm{L}$ of RedSafe ${ }^{\mathrm{TM}}$ (iNtRON Biotechnology, Kirkland, WA, USA) conducted in $1 \times$ Tris-Borate-EDTA (TBE) (1st BASE Biochemicals, Singapore Science Park II, Singapore) buffer at $70 \mathrm{~V}$ until the tracking dye travelled three-quarters of the gel. Gel picture was visualized, and the image was captured using Gel Documentation System Fusion FX7-7026 (Vilber Lourmat, Marne-la-Vallée, France).

The RNA is said to be intact if the band intensity (28S:18S ratio) is 2:1. Complementary DNA (cDNA) was synthesized using the protocol of the GoTaq ${ }^{\circledR}$ 2-Step RT-qPCR System (Promega, Madison, WI, USA) with minor adjustments, whereby 2500 ng of RNA were transcribed in $20 \mu \mathrm{L}$ of total reaction mixture. In total, $250 \mathrm{ng}$ of RNA equivalent cDNA were used in RT-PCR reaction mixture and $50 \mathrm{nM}$ of primers (Table 3) were used for each gene. The reaction was conducted using StepOnePlus ${ }^{\text {TM }}$ RT-PCR Systems (Applied Biosystems, Foster City, CA, USA) following the cycling conditions shown in Table 4. For no template control (NTC), the cDNA template was replaced with nuclease-free water. For no reverse transcriptase control (NORT), RNA mixture without GoScript ${ }^{\mathrm{TM}}$ Reverse Transcriptase, random, and oligo $(\mathrm{dT})_{15}$ primers was used in place of the cDNA template. CCND1, CDK4, $T E R T$, and TERC levels were normalized to the geomean of glyceraldehyde-3-phosphate dehydrogenase (GAPDH) and $A C T B$.

Table 3. Primer sequences used in RT-PCR.

\begin{tabular}{|c|c|c|c|c|}
\hline NCBI ID & Gene & Forward $\left(5^{\prime}\right.$ to $\left.3^{\prime}\right)$ & Reverse $\left(5^{\prime}\right.$ to $\left.3^{\prime}\right)$ & Amplicon Size (bp) \\
\hline 7015 & TERT & ACTGCGTGCGTCGGTATGC & CGGCTGGAGGTCTGTCAAGGTA & 97 \\
\hline 7012 & TERC & AGAGGAACGGAGCGAGTC & GCATGTGTGAGCCGAGTC & 80 \\
\hline 595 & CCND1 & AACACGGCTCACGCTTACC & GCCCCATCACGACAGACAAAG & 94 \\
\hline 1019 & $C D K 4$ & ATGTGGAGTGTTGGCTGTATC & CTGGTCGGCTTCAGAGTTTC & 78 \\
\hline 2597 & GAPDH & TTGGTATCGTGGAAGGACTCA & CCAGTAGAGGCAGGGATGAT & 133 \\
\hline 60 & $A C T B$ & CGTCTTCCСCTCCATCGT & GCCTCGTCGCCCACATAG & 87 \\
\hline
\end{tabular}

Table 4. Cycling conditions for RT-PCR.

\begin{tabular}{cccc}
\hline Step & Cycles & Temperature $\left({ }^{\circ} \mathbf{C}\right)$ & Duration \\
\hline GoTaq $^{\circledR}$ Hot Start Polymerase activation & 1 & 95 & $2 \mathrm{~min}$ \\
\hline Denaturation & & 95 & $15 \mathrm{~s}$ \\
Annealing & 40 & 53.5 & $30 \mathrm{~s}$ \\
Extension & & 60 & $30 \mathrm{~s}$ \\
\hline Dissociation & 1 & 60 to 95 & $5 \mathrm{~min}$ \\
Hold & & 10 & $\infty$ \\
\hline
\end{tabular}

\subsection{Relative Telomere Length Quantification}

Genomic DNA (gDNA) extraction was conducted using the protocol of the QuickDNA $^{\mathrm{TM}}$ Miniprep Plus Kit (Zymo Research, Irvine, CA, USA). In total, $1 \times 10^{6}$ harvested cells were used for the gDNA extraction. A NanoDrop ${ }^{\text {TM }} 2000$ was used for gDNA quantification and quality assessment. The quantification of the relative telomere length was done according to Vasilishina et al. [62] with minor adjustments, whereby $10 \mathrm{ng}$ of gDNA and a GoTaq $^{\circledR}$ 2-Step RT-qPCR System were used. The amplification was done for 40 cycles and conducted using StepOnePlus ${ }^{\mathrm{TM}}$ RT-PCR Systems. Single copy gene (SCG), interferon beta 1 (IFNB1) was used for normalization. 


\subsection{Western Blot}

In total, $1 \times 10^{6}$ harvested cells were lysed in $60 \mu \mathrm{L}$ Radio Immunoprecipitation Assay (RIPA) lysis buffer containing $1 \%$ protease inhibitor cocktail, sonicated on ice bath for $1 \mathrm{~min}$, incubated for $30 \mathrm{~min}$ on ice, followed by centrifugation at $14,000 \times \mathrm{g}$ for $15 \mathrm{~min}$ to pellet the cell debris, and subjected to protein estimation by employing Bradford Assay. Then, $20 \mu \mathrm{g}$ of total protein denatured at $70{ }^{\circ} \mathrm{C}$ were separated on $4 \%$ and $12 \%$ SDS-polyacrylamide stacking and resolving gels, respectively. Electrophoresis was done at $80 \mathrm{~V}$ for $30 \mathrm{~min}$, followed by $100 \mathrm{~V}$ for $1 \mathrm{~h} 40 \mathrm{~min}$ using pre-chilled $\left(4^{\circ} \mathrm{C}\right) 1 \times \mathrm{SDS}$ running buffer, followed by protein transferring onto $0.22-\mu \mathrm{m}$ nitrocellulose membrane (Pall Corp., Morelos, Mexico). Electroblotting was conducted using a Mini-Protean ${ }^{\circledR}$ Tetra System (Bio-Rad Laboratories, Hercules, CA, USA) with pre-chilled $\left(-20^{\circ} \mathrm{C}\right) 1 \times$ SDS transfer buffer and ice pack $(-80$ $\left.{ }^{\circ} \mathrm{C}\right)$ for $1 \mathrm{~h} 40 \mathrm{~min}$ on ice. The membrane was removed and incubated in Blocking One (Nacalai Tesque, Kyoto, Japan) for $1 \mathrm{~h}$ at room temperature, on a shaker at $100 \mathrm{rpm}$. The membrane was incubated for at least $13 \mathrm{~h}$ in a cold room $\left(5-10^{\circ} \mathrm{C}\right)$ and was constantly shaken at $90 \mathrm{rpm}$ in monoclonal primary antibody at 1:1000 dilution for ACTB and 1:100 dilution for CCND1, CDK4, and TERT, respectively, in Blocking One. The membrane was then washed 3 times with $1 \times$ Tris-buffered saline containing $0.1 \%$ Tween 20 (TBST), 5 min each time, and on a shaker at $120 \mathrm{rpm}$. The membrane was incubated on a shaker at 90 rpm with m-IgGk BP-HRP at 1:10,000 dilution in Blocking One for $2 \mathrm{~h}$ at room temperature. The $1 \times$ TBST washing step was repeated as previously stated. The membranes were incubated in chemiluminescence solution of Western Bright Sirius (Advansta, San Jose, CA, USA) following the manufacturer's protocol before the membrane was visualized, and the image was captured using Gel Documentation System Fusion FX7-7026 (Vilber Lourmat, Marne-la-Vallée, France). ACTB was used as the loading control. Protein signal intensities were analyzed by using ImageJ version 1.52a. CCND1, CDK4, and TERT protein signal intensities were normalized to the loading control.

\subsection{Statistical Analysis}

All data obtained in this study were subjected to either $t$-test or one-way ANOVA. Statistical values were expressed as mean \pm standard error. $p$-values $<0.05,<0.01$, and $<0.001$ were considered as statistically significant, very statistically significant, and highly statistically significant, respectively. Mean values were compared using Duncan's Multiple Range Test (DMRT). Most statistical analyses were conducted using either Microsoft ${ }^{\circledR}$ Office Excel version 365 or IBM SPSS Statistics version 23.

\section{Conclusions}

In summary, our study demonstrated that berberine decreased the telomerase activity in HCT 116 by simultaneous downregulation of TERT and TERC levels, which resulted in a decrease of the TERT protein level. Berberine induced $\mathrm{G}_{0} / \mathrm{G}_{1}$ arrest by the upregulation of CCND1 and downregulation of CDK4, whereby the effect of berberine on the cell cycle was time dependent. Telomerase activity of HCT 116 was decreased by berberine treatment and the telomere length was also significantly eroded. Elucidation of berberine's potential as a telomerase inhibitor in CRC would require further extensive and elaborative efforts in the future.

Author Contributions: J.S.Y., N.A.M., M.A.S. and M.Z.S. conceived and designed the experiment(s), M.A.S. conducted the experiment(s) and wrote the manuscript, M.A.S., J.S.Y., M.Z.S. and N.A.M. analyzed the results. J.S.Y., S.A.K., N.A.M. and M.A.S. contributed reagents/materials/experimental tools. All authors have read and agreed to the published version of the manuscript.

Funding: This research was funded by University Malaya (Grant No. RP030C-15AFR, RU004C-2020 and CEBAR RU006-2018).

Acknowledgments: The authors thank Universiti Malaya, Malaysia for experimental facilities and financial support (Grant Number: RP030C-15AFR, RU004C-2020 and CEBAR RU006-2018) provided. 
Conflicts of Interest: The authors declare no conflict of interest. The funders had no role in the design of the study; in the collection, analyses, or interpretation of data; in the writing of the manuscript, or in the decision to publish the results.

Sample Availability: Samples of the compounds are not available from the authors.

\section{Appendix A}

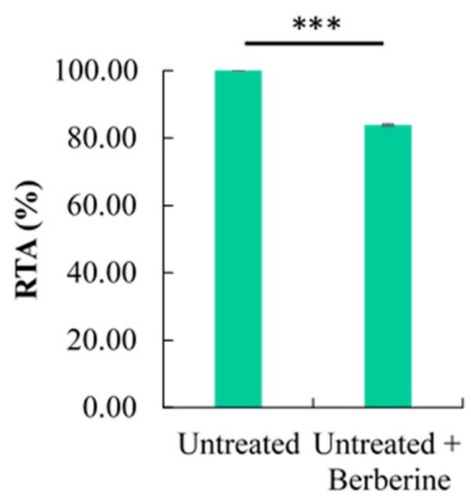

Figure A1. Cell-free telomerase inhibition by direct addition of berberine in the TRAP reaction mixture of untreated HCT 116 cell lysate. The relative telomerase activity (RTA) of untreated HCT 116 cell lysate added with berberine was $83.90 \pm 0.34 \%$. Berberine only decreased the RTA of untreated HCT 116 cell lysate by $16.10 \%$. Values are mean \pm standard error of triplicate. Mean with $* * *$ (triple asterisks) differ significantly at $p<0.001$.

\section{References}

1. Ferlay, J.; Colombet, M.; Soerjomataram, I.; Mathers, C.; Parkin, D.M.; Piñeros, M.; Znaor, A.; Bray, F. Estimating the global cancer incidence and mortality in 2018: Globocan sources and methods. Int. J. Cancer 2019, 144, 1941-1953. [CrossRef] [PubMed]

2. Chandrashekar, D.S.; Bashel, B.; Balasubramanya, S.A.H.; Creighton, C.J.; Ponce-Rodriguez, I.; Chakravarthi, B.; Varambally, S. Ualcan: A portal for facilitating tumor subgroup gene expression and survival analyses. Neoplasia 2017, 19, 649-658. [CrossRef] [PubMed]

3. Tatsumoto, N.; Hiyama, E.; Murakami, Y.; Imamura, Y.; Shay, J.W.; Matsuura, Y.; Yokoyama, T. High telomerase activity is an independent prognostic indicator of poor outcome in colorectal cancer. Clin. Cancer Res. 2000, 6, 2696-2701. [PubMed]

4. Zvereva, M.I.; Shcherbakova, D.M.; Dontsova, O.A. Telomerase: Structure, functions, and activity regulation. Biochem. Biokhim. 2010, 75, 1563-1583. [CrossRef] [PubMed]

5. Bertorelle, R.; De Rossi, A. Telomerase as biomarker in colorectal cancer. In Biomarkers in Cancer; Preedy, V.R., Patel, V.B., Eds.; Springer: Dordrecht, The Netherlands, 2015; pp. 659-683.

6. Chang, J.T.C.; Chen, Y.L.; Yang, H.T.; Chen, C.Y.; Cheng, A.J. Differential regulation of telomerase activity by six telomerase subunits. Eur. J. Biochem. 2002, 269, 3442-3450. [CrossRef] [PubMed]

7. MacNeil, D.; Bensoussan, H.; Autexier, C. Telomerase regulation from beginning to the end. Genes 2016, 7, 64. [CrossRef]

8. Wyatt, H.D.M.; West, S.C.; Beattie, T.L. Intertpreting telomerase structure and function. Nucleic Acids Res. 2010, 38, 5609-5622. [CrossRef]

9. Nguyen, T.H.D.; Tam, J.; Wu, R.A.; Greber, B.J.; Toso, D.; Nogales, E.; Collins, K. Cryo-em structure of substrate-bound human telomerase holoenzyme. Nature 2018, 557, 190-195. [CrossRef]

10. Ganesan, K.; Xu, B. Telomerase inhibitors from natural products and their anticancer potential. Int. J. Mol. Sci. 2018, 19, 13. [CrossRef]

11. O'Brien, P.; Carrasco-Pozo, C.; Speisky, H. Boldine and its antioxidant or health-promoting properties. Chem. Biol. Interact. 2006, 159, 1-17. [CrossRef]

12. Brantley, S.J.; Oberlies, N.H.; Kroll, D.J.; Paine, M.F. Two flavonolignans from milk thistle (silybum marianum) inhibit cyp2c9mediated warfarin metabolism at clinically achievable concentrations. J. Pharmacol. Exp. Ther. 2010, 332, 1081-1087. [CrossRef] [PubMed]

13. Davis-Searles, P.R.; Nakanishi, Y.; Kim, N.-C.; Graf, T.N.; Oberlies, N.H.; Wani, M.C.; Wall, M.E.; Agarwal, R.; Kroll, D.J. Milk thistle and prostate cancer: Differential effects of pure flavonolignans from silybum marianum on antiproliferative end points in human prostate carcinoma cells. Cancer Res. 2005, 65, 4448-4457. [CrossRef] [PubMed]

14. Surai, P. Silymarin as a natural antioxidant: An overview of the current evidence and perspectives. Antioxidants 2015, 4, 204-247. [CrossRef] 
15. Mahata, S.; Bharti, A.C.; Shukla, S.; Tyagi, A.; Husain, S.A.; Das, B.C. Berberine modulates ap-1 activity to suppress hpv transcription and downstream signaling to induce growth arrest and apoptosis in cervical cancer cells. Mol. Cancer 2011, 10, 39. [CrossRef]

16. Srinivasan, G.V.; Unnikrishnan, K.P.; Rema Shree, A.B.; Balachandran, I. Hplc estimation of berberine in tinospora cordifolia and tinospora sinensis. Indian J. Pharm. Sci. 2008, 70, 96-99. [CrossRef] [PubMed]

17. Eskandari-Nasab, E.; Dahmardeh, F.; Rezaeifar, A.; Dahmardeh, T. Telomere and telomerase: From discovery to cancer treatment. Gene Cell Tissue 2015, 2, e28084. [CrossRef]

18. Hiyama, E.; Hiyama, K. Telomere and telomerase in stem cells. Br. J. Cancer 2007, 96, 1020-1024. [CrossRef] [PubMed]

19. Noureini, S.K.; Wink, M. Dose-dependent cytotoxic effects of boldine in hepg-2 cells-telomerase inhibition and apoptosis induction. Molecules 2015, 20, 3730-3743. [CrossRef]

20. Zhu, X.; Kumar, R.; Mandal, M.; Sharma, N.; Sharma, H.W.; Dhingra, U.; Sokoloski, J.A.; Hsiao, R.; Narayanan, R. Cell cycledependent modulation of telomerase activity in tumor cells. Proc. Natl. Acad. Sci. USA 1996, 93, 6091-6095. [CrossRef]

21. Klein, E.A.; Assoian, R.K. Transcriptional regulation of the cyclin d1 gene at a glance. J. Cell Sci. 2008, 121, 3853-3857. [CrossRef]

22. Ioset, J.-R.; Brun, R.; Wenzler, T.; Kaiser, M.; Yardley, V. Drug screening for kinetoplastids diseases. In A Training Manual for Screening in Neglected Diseases; Department for International Development: London, UK, 2009.

23. National Cancer Institute. Nci-60 Screening Methodology. Available online: https://dtp.cancer.gov/discovery_development/ nci-60/methodology.htm (accessed on 19 May 2019).

24. Barzegar, E.; Fouladdel, S.; Movahhed, T.K.; Atashpour, S.; Ghahremani, M.H.; Ostad, S.N.; Azizi, E. Effects of berberine on proliferation, cell cycle distribution and apoptosis of human breast cancer $\mathrm{t} 47 \mathrm{~d}$ and mcf7 cell lines. Iran. J. Basic Med. Sci. 2015, 18, 334. [PubMed]

25. Li, F.; Dong, X.; Lin, P.; Jiang, J. Regulation of akt/foxo3a/skp2 axis is critically involved in berberine-induced cell cycle arrest in hepatocellular carcinoma cells. Int. J. Mol. Sci. 2018, 19, 327.

26. Chen, Q.; Qin, R.; Fang, Y.; Li, H. Berberine sensitizes human ovarian cancer cells to cisplatin through mir-93/pten/akt signaling pathway. Cell. Physiol. Biochem. 2015, 36, 956-965. [CrossRef] [PubMed]

27. Jirawatnotai, S.; Hu, Y.; Livingston, D.M.; Sicinski, P. Proteomic identification of a direct role for cyclin d1 in DNA damage repair. Cancer Res. 2012, 72, 4289-4293. [CrossRef]

28. Wang, Y.Y.; Sun, G.; Luo, H.; Wang, X.F.; Lan, F.M.; Yue, X.; Fu, L.S.; Pu, P.Y.; Kang, C.S.; Liu, N. Mir-21 modulates h tert through a stat3-dependent manner on glioblastoma cell growth. CNS Neurosci. Ther 2012, 18, 722-728. [CrossRef]

29. Lin, C.-Y.; Hsieh, P.-L.; Liao, Y.-W.; Peng, C.-Y.; Lu, M.-Y.; Yang, C.-H.; Yu, C.-C.; Liu, C.-M. Correction: Berberine-targeted mir-21 chemosensitizes oral carcinomas stem cells. Oncotarget 2018, 9, 24870. [CrossRef]

30. Xin, X.; Senthilkumar, P.; Schnoor, J.L.; Ludewig, G. Effects of pcb126 and pcb153 on telomerase activity and telomere length in undifferentiated and differentiated hl-60 cells. Environ. Sci. Pollut. Res. 2016, 23, 2173-2185. [CrossRef]

31. Wu, K.; Yang, Q.; Mu, Y.; Zhou, L.; Liu, Y.; Zhou, Q.; He, B. Berberine inhibits the proliferation of colon cancer cells by inactivating wnt/ $\beta$-catenin signaling. Int. J. Oncol. 2012, 41, 292-298.

32. Brattain, M.G.; Fine, W.D.; Khaled, F.M.; Thompson, J.; Brattain, D.E. Heterogeneity of malignant cells from a human colonic carcinoma. Cancer Res. 1981, 41, 1751-1756.

33. Owa, T.; Ozawa, Y.; Semba, T. Joint Use of Sulfonamide Based Compound with Angiogenesis Inhibitor. EP Patent 2,364,699,A1, 14 September 2011.

34. Jain, M.; Nilsson, R.; Sharma, S.; Madhusudhan, N.; Kitami, T.; Souza, A.L.; Kafri, R.; Kirschner, M.W.; Clish, C.B.; Mootha, V.K. Metabolite profiling identifies a key role for glycine in rapid cancer cell proliferation. Science 2012, 336, 1040-1044. [CrossRef]

35. Pereira, P.D.; Serra-Caetano, A.; Cabrita, M.; Bekman, E.; Braga, J.; Rino, J.; Santus, R.; Filipe, P.L.; Sousa, A.E.; Ferreira, J.A. Quantification of cell cycle kinetics by edu (5-ethynyl-2'-deoxyuridine)-coupled-fluorescence-intensity analysis. Oncotarget 2017, 8, 40514. [CrossRef] [PubMed]

36. National Cancer Institute. Cell Lines in the in vitro screen. Available online: https://dtp.cancer.gov/discovery_development/ nci-60/cell_list.htm (accessed on 10 April 2019).

37. Nguyen, D.; Grenier St-Sauveur, V.; Bergeron, D.; Dupuis-Sandoval, F.; Scott, M.S.; Bachand, F. A polyadenylation-dependent $3^{\prime}$ end maturation pathway is required for the synthesis of the human telomerase rna. Cell Rep. 2015, 13, 2244-2257. [CrossRef] [PubMed]

38. Serafim, T.L.; Oliveira, P.J.; Sardao, V.A.; Perkins, E.; Parke, D.; Holy, J. Different concentrations of berberine result in distinct cellular localization patterns and cell cycle effects in a melanoma cell line. Cancer Chemther. Pharmacol. 2008, 61, 1007-1018. [CrossRef] [PubMed]

39. Guaman Ortiz, L.M.; Croce, A.L.; Aredia, F.; Sapienza, S.; Fiorillo, G.; Syeda, T.M.; Buzzetti, F.; Lombardi, P.; Scovassi, A.I. Effect of new berberine derivatives on colon cancer cells. Acta Biochimica Biophysica Sinica 2015, 47, 824-833. [CrossRef]

40. Li, W.; Hua, B.; Saud, S.M.; Lin, H.; Hou, W.; Matter, M.S.; Jia, L.; Colburn, N.H.; Young, M.R. Berberine regulates amp-activated protein kinase signaling pathways and inhibits colon tumorigenesis in mice. Mol. Carcinogenes. 2015, 54, 1096-1109. [CrossRef]

41. Noureini, S.K.; Tanavar, F. Boldine, a natural aporphine alkaloid, inhibits telomerase at non-toxic concentrations. Chem.-Biol. Interact. 2015, 231, 27-34. [CrossRef]

42. Ko, E.; Seo, H.W.; Jung, G. Telomere length and reactive oxygen species levels are positively associated with a high risk of mortality and recurrence in hepatocellular carcinoma. Hepatology 2018, 67, 1378-1391. [CrossRef] 
43. Moraca, F.; Amato, J.; Ortuso, F.; Artese, A.; Pagano, B.; Novellino, E.; Alcaro, S.; Parrinello, M.; Limongelli, V. Ligand binding to telomeric g-quadruplex DNA investigated by funnel-metadynamics simulations. Proc. Natl. Acad. Sci. USA 2017, 114, E2136-E2145. [CrossRef]

44. Bhadra, K.; Kumar, G.S. Interaction of berberine, palmatine, coralyne, and sanguinarine to quadruplex DNA: A comparative spectroscopic and calorimetric study. Biochimica Biophysica Acta 2011, 1810, 485-496. [CrossRef]

45. Neidle, S. Quadruplex nucleic acids as novel therapeutic targets. J. Med. Chem. 2016, 59, 5987-6011. [CrossRef]

46. Wang, Y.; Kheir, M.M.; Chai, Y.; Hu, J.; Xing, D.; Lei, F.; Du, L. Comprehensive study in the inhibitory effect of berberine on gene transcription, including tata box. PLoS ONE 2011, 6, e23495. [CrossRef] [PubMed]

47. Yuan, Z.-Y.; Lu, X.; Lei, F.; Chai, Y.-S.; Wang, Y.-G.; Jiang, J.-F.; Feng, T.-S.; Wang, X.-P.; Yu, X.; Yan, X.-J. Tata boxes in gene transcription and poly (a) tails in mrna stability: New perspective on the effects of berberine. Sci. Rep. 2015, 5, 18326. [CrossRef]

48. Fu, L.; Chen, W.; Guo, W.; Wang, J.; Tian, Y.; Shi, D.; Zhang, X.; Qiu, H.; Xiao, X.; Kang, T. Berberine targets ap-2/htert, nf-kb/cox-2, hif-1 $\alpha$ /vegf and cytochrome-c/caspase signaling to suppress human cancer cell growth. PLoS ONE 2013, 8, e69240. [CrossRef] [PubMed]

49. Xiong, Y.X.; Su, H.F.; Lv, P.; Ma, Y.; Wang, S.K.; Miao, H.; Liu, H.Y.; Tan, J.H.; Ou, T.M.; Gu, L.Q.; et al. A newly identified berberine derivative induces cancer cell senescence by stabilizing endogenous g-quadruplexes and sparking a DNA damage response at the telomere region. Oncotarget 2015, 6, 35625-35635. [CrossRef] [PubMed]

50. Gutierrez-Rodrigues, F.; Santana-Lemos, B.A.; Scheucher, P.S.; Alves-Paiva, R.M.; Calado, R.T. Direct comparison of flow-fish and qpcr as diagnostic tests for telomere length measurement in humans. PLoS ONE 2014, 9, e113747. [CrossRef] [PubMed]

51. Arora, A.; Balasubramanian, C.; Kumar, N.; Agrawal, S.; Ojha, R.P.; Maiti, S. Binding of berberine to human telomeric quadruplexSpectroscopic, calorimetric and molecular modeling studies. FEBS J. 2008, 275, 3971-3983. [CrossRef] [PubMed]

52. Bazzicalupi, C.; Ferraroni, M.; Bilia, A.R.; Scheggi, F.; Gratteri, P. The crystal structure of human telomeric DNA complexed with berberine: An interesting case of stacked ligand to g-tetrad ratio higher than 1:1. Nucleic Acids Res. 2013, 41, 632-638. [CrossRef] [PubMed]

53. Zhang, W.J.; Ou, T.M.; Lu, Y.J.; Huang, Y.Y.; Wu, W.B.; Huang, Z.S.; Zhou, J.L.; Wong, K.Y.; Gu, L.Q. 9-substituted berberine derivatives as g-quadruplex stabilizing ligands in telomeric DNA. Bioorg. Med. Chem. 2007, 15, 5493-5501. [CrossRef]

54. Xu, J.; Long, Y.; Ni, L.; Yuan, X.; Yu, N.; Wu, R.; Tao, J.; Zhang, Y. Anticancer effect of berberine based on experimental animal models of various cancers: A systematic review and meta-analysis. BMC Cancer 2019, 19, 589. [CrossRef]

55. Zhang, J.; Cao, H.; Zhang, B.; Cao, H.; Xu, X.; Ruan, H.; Yi, T.; Tan, L.; Qu, R.; Song, G. Berberine potently attenuates intestinal polyps growth in apcmin mice and familial adenomatous polyposis patients through inhibition of wnt signalling. J. Cell. Mol. Med. 2013, 17, 1484-1493. [CrossRef]

56. Assefa, A.T.; Vandesompele, J.; Thas, O. On the utility of rna sample pooling to optimize cost and statistical power in rna sequencing experiments. BMC Genom. 2020, 21, 1-14. [CrossRef]

57. Metzger, K.; Tuchscherer, A.; Palin, M.-F.; Ponsuksili, S.; Kalbe, C. Establishment and validation of cell pools using primary muscle cells derived from satellite cells of pig skeletal muscle. In Vitro Cell. Dev. Biol. Anim. 2019, 1-7. [CrossRef] [PubMed]

58. Diz, A.P.; Truebano, M.; Skibinski, D.O. The consequences of sample pooling in proteomics: An empirical study. Electrophoresis 2009, 30, 2967-2975. [CrossRef] [PubMed]

59. Phang, C.-W.; Karsani, S.A.; Sethi, G.; Malek, S.N.A. Flavokawain c inhibits cell cycle and promotes apoptosis, associated with endoplasmic reticulum stress and regulation of mapks and akt signaling pathways in hct 116 human colon carcinoma cells. PLoS ONE 2016, 11, e0148775. [CrossRef] [PubMed]

60. Sebaugh, J. Guidelines for accurate ec50/ic50 estimation. Pharm. Stat. 2011, 10, 128-134. [CrossRef] [PubMed]

61. Schneider, C.A.; Rasband, W.S.; Eliceiri, K.W. Nih image to imagej: 25 years of image analysis. Nature Methods 2012, 9, 671-675. [CrossRef]

62. Vasilishina, A.; Kropotov, A.; Spivak, I.; Bernadotte, A. Relative human telomere length quantification by real-time pcr. In Cellular Senescence; Springer: Berlin/Heidelberg, Germany, 2019; pp. 39-44. 